\title{
Orthopaedics and COVID-19: The surgery, the surgeon and the susceptible - a scoping review
}

\author{
O'Connor $\mathrm{M}^{1} \mathbb{1}$, Nieuwoudt $\mathrm{L}^{2}$, , Marais $\mathrm{LC}^{3}$ (i)
}

1 MBBCh, FC Orth SA; Consultant, Department of Orthopaedic Surgery, University of KwaZulu-Natal; GJGM Memorial Hospital, KwaDukuza, Durban, South Africa

2 MBChB, FC Orth SA; Consultant, Department of Orthopaedic Surgery, University of KwaZulu-Natal; Grey's Hospital, Pietermaritzburg, South Africa

${ }_{3}$ MBChB, FC Orth SA, PhD; Head of Department: Orthopaedics, School of Clinical Medicine, University of KwaZulu-Natal, Durban, South Africa

Corresponding author: Dr Megan O'Connor, Department of Orthopaedic Surgery, GJGM Memorial Hospital, 23A King Shaka Street, KwaDukuza, Durban, 4450, South Africa; tel: 082441 0295; email: megsapod@gmail.com

\begin{abstract}
Background: The coronavirus disease of 2019 (COVID-19) pandemic is taxing South Africa's already over-burdened healthcare system. Orthopaedics is not exempt; patients present with COVID-19 and musculoskeletal pathology and so surgeons should be familiar with the current evidence to best manage patients and themselves. The aims of this scoping review were firstly to inform peri-operative decision-making for COVID-positive patients as well as the routine orthopaedic milieu during the pandemic; secondly to assess the outcomes of orthopaedic patients managed in endemic areas; and finally to determine the effect the pandemic has had on our orthopaedic peers.
\end{abstract}

Methods: A scoping review was conducted following the PRISMA-ScR guidelines of 2018. The search terms 'Orthopaedics' or 'Orthopedics' and 'COVID-19' or 'Coronavirus' were used to perform the search on Scopus, PubMed and Cochrane databases. All peer-reviewed articles utilising evidence-based methodology and addressing one of the objectives were eligible. A thematic approach was used for qualitative data synthesis.

Results: Seventeen articles were identified for inclusion. All articles represented level 4 and 5 evidence and comprised ten reviewtype articles, one consensus statement, two web-based surveys and four observational studies. Most articles $(n=11)$ addressed the objective of peri-operative considerations covering the stratification and testing of patients, theatre precautions and personal protective equipment (PPE). Evidence suggests that patients should be stratified for surgery according to the urgency of their procedure, their risk of asymptomatic disease (related to the community prevalence of COVID-19) and their comorbidities. The consensus is that all patients should be screened (asked a set of standardised questions with regard their symptoms and contacts). Only symptomatic patients and those asymptomatic patients from high prevalence areas or those with high-risk contacts should be tested. Healthcare workers (HCWs) in theatre should maintain safety precautions considering every individual is a potential contact. In the operating room in addition to the standard orthopaedic surgery PPE, if a patient is COVID positive, surgeons should don an N95 respirator. The three articles that addressed the effects on the orthopaedic surgeon showed a significant redeployment rate, effects on monetary renumeration of specialists and also effects on surgeons in training causing negative emotional ramifications. Of the surgeons who have contracted the illness and have been investigated, all showed mild symptomatology and recovered fully. The final three articles concentrated on orthopaedic patient considerations; they all showed high mortality rates in the vulnerable patient populations investigated, but had significant limitations.

Conclusion: Orthopaedics is significantly affected by the COVID pandemic but there remains a dearth of high-quality evidence to guide the specialty.

Level of evidence: Level 3

Keywords: COVID-19, SARS-CoV-2, coronavirus, orthopaedic, surgery

Citation: O'Connor M, Nieuwoudt L, Marais LC. Orthopaedics and COVID-19: The surgery, the surgeon and the susceptible - a scoping review. SA Orthop J 2020;19(3):129-137. http://dx.doi.org/10.17159/2309-8309/2020/ v19n3a1

Editor: Prof. Nando Ferreira, Stellenbosch University, South Africa

Received: July 2020

Accepted: July 2020

Published: August 2020

Copyright: $\odot 2020$ O'Connor M. This is an open-access article distributed under the terms of the Creative Commons Attribution Licence, which permits unrestricted use, distribution and reproduction in any medium, provided the original author and source are credited.

Funding: No funding was required for this study.

Conflict of interest: The authors declare they have no conflicts of interest that are directly or indirectly related to the research. 


\section{Introduction}

The first case of COVID-19 illness in South Africa (SA), caused by the severe acute respiratory syndrome coronavirus-2 (SARSCoV-2), was diagnosed on 5 March 2020. This was several months after the index case in Wuhan, People's Republic of China. South Africa observed as the World Health Organization (WHO) declared the pandemic on 11 March and as it coursed the globe, declaring a national state of disaster and an eight-stage response to the pandemic on 24 March.

In the initial stages, a national lockdown was instituted and a rigorous public screening and testing programme was established in an attempt to flatten the curve. South Africa faces many of the healthcare challenges experienced globally, such as a shortage of test reagent and acquisition of personal protective equipment (PPE) to name a few. In addition, it is encumbered with the greatest human immunodeficiency virus (HIV) burden in the world, and the strain of $80 \%$ of the population reliant on the public service for care. $^{1}$

Currently, in the midst of the surge, each sector of the South African healthcare team has a duty to respond to the pandemic as it affects their field. We acknowledge that while orthopaedics is not on the frontline in medically managing the illness, we will encounter COVID-19 patients during our scope of practice and be required to use resources responsibly, offering support to more burdened sectors. Knowledge of infection control and prevention measures has been shown to have a protective effect on contraction of the COVID-19 illness. ${ }^{2}$ Therein the aim of the study, to keep orthopaedic surgeons informed.

Three objectives were identified to achieve this end:

1. To outline the peri-operative considerations highlighted in literature.
2. To assess the current evidence on orthopaedic patients and their outcomes.

3. To evaluate the effect the pandemic has had on our international orthopaedic counterparts.

While there is a plethora of anecdotal evidence in the form of current status quo, there is a paucity of evidenced-based data, making presentation of the information suited to a scoping format.

\section{Methods}

We conducted a scoping review following the PRISMA-ScR guidelines of $2018 .^{3}$ Peer-reviewed articles pertaining to orthopaedic surgery and COVID-19 were considered eligible for inclusion. Requisite for inclusion was a focus on at least one of the three objectives. This included some peer-reviewed articles obtained online prior to print. Editorials, letters to the editor, commentaries, articles pertaining to general surgery (not orthopaedic-specific) and situation reports were excluded. After completion of full text review, one additional article was identified from a reference. Critical appraisal could not be performed in this analysis due to the heterogenous nature of the articles and broad thematic content.

The search was performed on 23 May 2020 on the Scopus, Cochrane and PubMed databases. The search was performed with the terms 'Orthopaedics' and 'Orthopedics' applying the Boolean operator 'OR'. Similarly, 'COVID-19' and 'coronavirus' were searched using 'OR' and the operator 'AND' was employed between the two groups. Limitations applied included English language articles and those published from December 2019 (Figure 1).

Search citations were exported to EndNote (EndNote X9.3.3, Michael O. McCracken) and transferred to Excel (Microsoft Excel for Mac version 16.31, Microsoft Corporation) for data collation. For

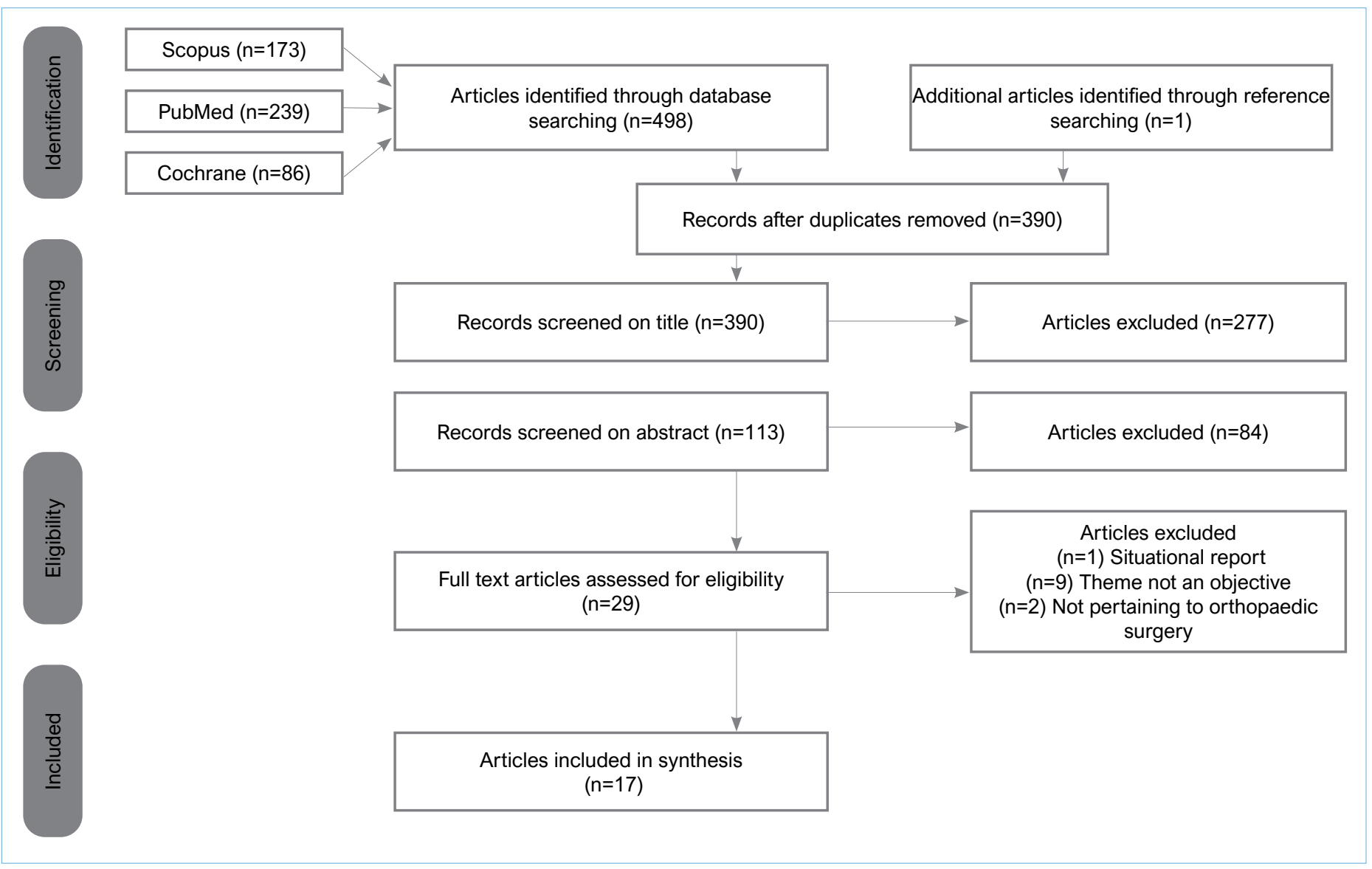

Figure 1. Flow diagram depicting article selection for review ${ }^{3}$ 
qualitative synthesis, columns were added to the spreadsheet to capture the article type, date of publication, country of origin, level of evidence, main theme or objective of the article as well as subthemes. A comments column was included for additional points of interest. Two authors independently performed title, abstract and full text reviews in this format. In the event of disagreement, consensus was reached by discussion.

\section{Results}

A total of 17 articles met the inclusion criteria. Eight articles represented level 4 evidence and nine articles level 5 evidence. These articles comprised ten reviews (literature, rapid, narrative or scoping types), three of which followed systematic approach guidelines. There was one consensus statement that applied the Delphi method, two web-based cross-sectional surveys and four observational cohort or case control studies. Contributions were made from across the globe, with one international report, five from the United States, five from Europe (namely Spain, Italy, Belgium and Scandinavia), three from India, and the remaining three came from China. Interestingly, the majority $(n=9)$ of the articles were published in May (actual print date and not the accessed date), reflecting a surge in publications immediately post-epidemiological peaks in Europe and America respectively. Some overlap was present regarding the main theme of each article; the majority of articles $(n=11)$ addressed the first objective encompassing peri-operative considerations, three addressed the effects on the orthopaedic surgeon, and the remaining three concentrated on orthopaedic patient outcomes. An article overview is represented in Table I. The main findings of each of the objectives are summarised hereafter.

\section{Peri-operative decision-making}

\section{Patient operative urgency grading, testing and risk stratification}

There is agreement on grading the level of urgency of surgery for patients; however, a standard nomenclature has not emerged.

Table I: Summarised details of reviewed articles

\begin{tabular}{|c|c|c|c|c|c|c|c|}
\hline & $\begin{array}{l}\text { Primary } \\
\text { author }\end{array}$ & Journal & $\begin{array}{l}\text { Date } \\
\text { published }\end{array}$ & Title & Origin & Article type & $\begin{array}{l}\text { Level of } \\
\text { evidence }\end{array}$ \\
\hline \multirow{11}{*}{ 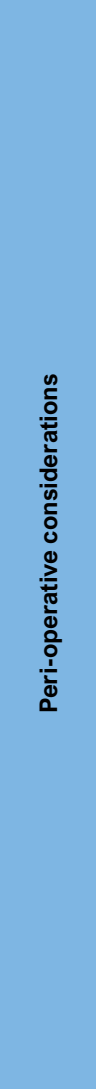 } & Viswanath & $\begin{array}{l}\text { Journal of Clinical } \\
\text { Orthopaedics and Trauma }\end{array}$ & 26 Mar 20 & $\begin{array}{l}\text { Working through the COVID-19 outbreak: Rapid } \\
\text { review and recommendations for MSK and allied heath } \\
\text { personnel }\end{array}$ & Delhi & $\begin{array}{l}\text { Rapid } \\
\text { review }\end{array}$ & 5 \\
\hline & Hirschman & $\begin{array}{l}\text { Knee Surgery, } \\
\text { Sports Traumatology, } \\
\text { Arthroscopy }\end{array}$ & 27 Apr 20 & $\begin{array}{l}\text { COVID-19 coronavirus: recommended personal } \\
\text { protective equipment for the orthopaedic and trauma } \\
\text { surgeon }\end{array}$ & Europe & Narrative review & 4 \\
\hline & Awad & $\begin{array}{l}\text { The Journal of the } \\
\text { American Academy of } \\
\text { Orthopaedic Surgeons }\end{array}$ & 10 Apr 20 & $\begin{array}{l}\text { Peri-operative considerations in urgent surgical } \\
\text { care of suspected and confirmed COVID- } 19 \\
\text { orthopedic patients: Operating rooms protocols and } \\
\text { recommendations in the current COVID-19 pandemic }\end{array}$ & USA & $\begin{array}{l}\text { Literature } \\
\text { review }\end{array}$ & 5 \\
\hline & Fillingham & Journal of Arthroplasty & 20 Apr 20 & $\begin{array}{l}\text { Personal protective equipment: Current best practices } \\
\text { for orthopedic teams }\end{array}$ & USA & $\begin{array}{l}\text { Literature } \\
\text { review }\end{array}$ & 5 \\
\hline & Ding & International Orthopaedics & 15 May 20 & $\begin{array}{l}\text { Time-sensitive ambulatory orthopaedic soft-tissue } \\
\text { surgery paradigms during the COVID-19 pandemic }\end{array}$ & Belgium & Scoping review & 4 \\
\hline & Basso & Acta Orthopaedica & 14 May 20 & $\begin{array}{l}\text { Virus transmission during orthopedic surgery on } \\
\text { patients with COVID-19 - a brief narrative review }\end{array}$ & Scandinavia & Literature review & 5 \\
\hline & Tang & Chinese Medical Journal & 05 May 20 & $\begin{array}{l}\text { Expert consensus on management principles of } \\
\text { orthopedic emergency in the epidemic of coronavirus } \\
\text { disease } 2019\end{array}$ & China & $\begin{array}{l}\text { Consensus } \\
\text { statement - } \\
\text { Delphi }\end{array}$ & 5 \\
\hline & Service & $\begin{array}{l}\text { Journal of Bone and Joint } \\
\text { Surgery America }\end{array}$ & 13 May 20 & $\begin{array}{l}\text { Medically necessary orthopaedic surgery during the } \\
\text { COVID-19 pandemic: Safe surgical practices and a } \\
\text { classification to guide treatment }\end{array}$ & USA & Literature review & 5 \\
\hline & Prada & Orthoevidence & 01 Jun 20 & $\begin{array}{l}\text { Best practices for surgeons COVID-19 evidence- } \\
\text { based scoping review: A unifying report of global } \\
\text { recommendations }\end{array}$ & International & Scoping review & 4 \\
\hline & Massey & $\begin{array}{l}\text { The Journal of the } \\
\text { American Academy of } \\
\text { Orthopaedic Surgeons }\end{array}$ & 01 Jun 20 & $\begin{array}{l}\text { Orthopaedic surgical selection and inpatient paradigms } \\
\text { during the coronavirus COVID-19 pandemic }\end{array}$ & USA & Literature review & 5 \\
\hline & Kumar & $\begin{array}{l}\text { Journal of Clinical } \\
\text { Orthopaedics and Trauma }\end{array}$ & 12 May 20 & $\begin{array}{l}\text { Perioperative COVID-19 testing of orthopedic patients: } \\
\text { Current evidence }\end{array}$ & India & $\begin{array}{l}\text { Literature } \\
\text { review }\end{array}$ & 5 \\
\hline \multirow{3}{*}{ 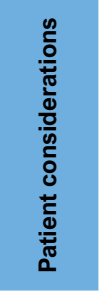 } & Catellani & $\begin{array}{l}\text { Journal of Bone and Joint } \\
\quad \text { Surgery America }\end{array}$ & 28 Apr 20 & $\begin{array}{l}\text { Treatment of proximal femoral fragility fractures in } \\
\text { patients with COVID-19 during the SARS-CoV-2 } \\
\text { outbreak in Northern Italy }\end{array}$ & Italy & Cohort & 4 \\
\hline & $\mathrm{Mi}$ & $\begin{array}{l}\text { Journal of Bone and Joint } \\
\text { Surgery America }\end{array}$ & 06 May 20 & $\begin{array}{l}\text { Characteristics and early prognosis of COVID-19 } \\
\text { infection in fracture patients }\end{array}$ & China & Cohort & 4 \\
\hline & $\begin{array}{l}\text { Muñoz } \\
\text { Vives }\end{array}$ & $\begin{array}{l}\text { Journal of Bone and Joint } \\
\text { Surgery America }\end{array}$ & 06 May 20 & $\begin{array}{l}\text { Mortality rates of patients with proximal femoral fracture } \\
\text { in a worldwide pandemic: Preliminary results of the } \\
\text { Spanish HIP-COVID observational study }\end{array}$ & Spain & Case control & 4 \\
\hline \multirow{3}{*}{ 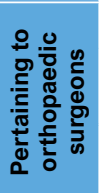 } & Culp & Journal of Arthroplasty & 24 Apr 20 & COVID-19 impact on young arthroplasty surgeons & USA & Survey & 4 \\
\hline & Sahu & $\begin{array}{l}\text { Journal of Clinical } \\
\text { Orthopaedics and Trauma }\end{array}$ & 12 May 20 & $\begin{array}{l}\text { Impact of COVID } 19 \text { lockdown on orthopaedic surgeons } \\
\text { in India: A survey }\end{array}$ & India & Survey & 4 \\
\hline & Guo & $\begin{array}{l}\text { Journal of Bone and Joint } \\
\quad \text { Surgery America }\end{array}$ & 20 May 20 & $\begin{array}{l}\text { Survey of COVID-19 disease among orthopaedic } \\
\text { surgeons in Wuhan, People's Republic of China }\end{array}$ & China & $\begin{array}{l}\text { Case control } \\
\text { survey }\end{array}$ & 4 \\
\hline
\end{tabular}


Table /I summarises the different terminologies utilised in the various texts and provides examples of cases ascribed to each grade. It is however not a fully comprehensive list, and several societies representing orthopaedic sub-disciplines have issued specific recommendations. ${ }^{4}$ The practical application of this is to guide patient selection based on the burden of COVID-19 on resources at any point in time..$^{5,6}$ In essence then, when the prevalence and resource demand is great, limit surgery only to emergency cases, but allow ongoing management of the routine burden when the COVID load is low. Singapore has adopted into policy DORSCON levels which represents phasing of their response based on resource demands and disease prevalence. ${ }^{7}$ The specific resource limitation should also be considered. If for example it is a bed shortage, one can endeavour to address surgeries on an outpatient or day case basis, in this way affording more access to the ongoing need. ${ }^{6}$ Ding et al. performed a review specifically on timing to surgery for traumatic soft tissue injuries in order to prevent negative outcomes. ${ }^{8}$
Testing patients for SARS-CoV-2 is considered to be necessary for a myriad of reasons. First, there is a high proportion of asymptomatic patients shedding viral matter (estimates vary across a wide range, from 5 to $80 \%$ ). Secondly, the incubation period is on average 5-14 days and the virus has proven highly contagious with a reproduction number $\left(R_{0}\right)$ of 2.68 , meaning that on average each COVID-positive person will infect 2.7 people..$^{5,9-11}$ Thirdly, there is a growing body of evidence to suggest patients with COVID-19 that undergo surgery have high morbidity and mortality rates. ${ }^{12-15}$ This should give us pause to earnestly evaluate the benefits of surgery in such patients who require life- or limb-saving surgery and should prompt us to involve a multidisciplinary team early on. ${ }^{9}$ Finally, it is self-evident that there will be far-reaching negative ramifications for any personnel involved in the intubation of a patient who is later found to be COVID positive.

In the ideal setting, each patient would be tested, but this is not feasible with a global reagent supply deficit. Also, the real-time polymerase chain reaction (RT-PCR) test offered in SA has a false

Table II: Summary recommendations of operative urgency stratification ${ }^{5,7-8}$

\begin{tabular}{|c|c|c|c|c|c|}
\hline Terminology & $\begin{array}{l}\text { Emergent } \\
\text { or } \\
\text { high acuity }\end{array}$ & Urgent & $\begin{array}{c}\text { Urgent } \\
\text { or } \\
\text { medium acuity } \\
\text { or } \\
\text { semi-urgent } \\
\text { or } \\
\text { expedited }\end{array}$ & Short-term delayed & $\begin{array}{c}\text { Elective } \\
\text { or } \\
\text { low acuity } \\
\text { or } \\
\text { non-urgent } \\
\text { or } \\
\text { long-term delayed }\end{array}$ \\
\hline Definition & $\begin{array}{c}\text { Requiring surgery } \\
\text { within } 24 \text { hours to save life } \\
\text { or limb }\end{array}$ & $\begin{array}{l}\text { Requiring surgery within } \\
48 \text { hours }\end{array}$ & $\begin{array}{l}\text { Needing surgery within } \\
2 \text { weeks or on the next } \\
\text { semi-elective slate }\end{array}$ & $\begin{array}{l}\text { Requiring surgery } \\
\text { within } 3 \text { months }\end{array}$ & $\begin{array}{c}\text { When surgery can be } \\
\text { delayed more than } 3 \\
\text { months without harm to the } \\
\text { patient }\end{array}$ \\
\hline $\begin{array}{l}\text { Tumours and } \\
\text { sepsis }\end{array}$ & $\begin{array}{l}\text { Necrotising fasciitis } \\
\text { Septic arthritis }\end{array}$ & $\begin{array}{l}\text { Impending pathological } \\
\text { fracture }\end{array}$ & & & Benign tumour procedures \\
\hline $\begin{array}{c}\text { Trauma } \\
\text { Foot and ankle }\end{array}$ & $\begin{array}{l}\text { Compound fractures or } \\
\text { impending compounds } \\
\text { Femur neck fractures in the } \\
\text { young } \\
\text { Bleeding pelvic fractures } \\
\text { Vascular injury } \\
\text { Compartment syndrome } \\
\text { External fixation for } \\
\text { complex fractures }\end{array}$ & $\begin{array}{l}\text { Femur neck and hip } \\
\text { fractures } \\
\text { Intertrochanteric femur } \\
\text { fractures } \\
\text { Talus neck fractures } \\
\text { Femur and tibia shaft } \\
\text { fractures }\end{array}$ & $\begin{array}{l}\text { Clavicle, scapula, humerus, } \\
\text { radius, ulna, ankle, tibial } \\
\text { plateau foot and pelvic and } \\
\text { acetabulum fractures } \\
\text { Acromioclavicular } \\
\text { dislocation } \\
\text { Delayed closure of wounds } \\
\text { and flaps over compound } \\
\text { fractures }\end{array}$ & & Ankle arthroplasty or fusion \\
\hline Spine & $\begin{array}{l}\text { Closed reduction of cervical } \\
\text { spine facet dislocation } \\
\text { Spinal cord injury } \\
\text { Epidural abscess or } \\
\text { haematoma drainage } \\
\text { Spinal tumour with cord } \\
\text { compression }\end{array}$ & $\begin{array}{l}\text { Cauda equina } \\
\text { decompression } \\
\text { Thoraco-lumbar fractures }\end{array}$ & & $\begin{array}{l}\text { Lumbar disc herniation with } \\
\text { radiculopathy } \\
\text { Cervical radiculopathy } \\
\text { Cervical myelopathy }\end{array}$ & $\begin{array}{l}\text { Spondylolisthesis } \\
\text { Spine deformity correction }\end{array}$ \\
\hline Arthroplasty & $\begin{array}{l}\text { Acute arthroplasty infection } \\
\text { Reduction of prosthetic joint } \\
\text { dislocation }\end{array}$ & Periprosthetic fractures & $\begin{array}{l}\text { Sub-acute arthroplasty } \\
\text { infection }\end{array}$ & & $\begin{array}{l}\text { Hip and knee arthroplasty } \\
\text { Revision arthroplasty }\end{array}$ \\
\hline Paediatrics & $\begin{array}{l}\text { Supracondylar humerus } \\
\text { fractures } \\
\text { Hip fracture dislocations } \\
\text { Slipped capital femoral } \\
\text { epiphysis }\end{array}$ & & Paediatric fractures & & \\
\hline $\begin{array}{l}\text { Hands and } \\
\text { shoulder }\end{array}$ & $\begin{array}{l}\text { Acute carpal tunnel } \\
\text { syndrome } \\
\text { Pyogenic flexor } \\
\text { tenosynovitis } \\
\text { Digit replantation } \\
\text { Reduction of joint } \\
\text { dislocation }\end{array}$ & & $\begin{array}{l}\text { Hand fractures } \\
\text { Tendon and ligament } \\
\text { injuries }\end{array}$ & $\begin{array}{l}\text { Chronic carpal tunnel } \\
\text { syndrome } \\
\text { Ulnar nerve compression } \\
\text { Rotator cuff repair in young } \\
\text { patients } \\
\text { Recurrent shoulder } \\
\text { dislocation for stabilisation }\end{array}$ & $\begin{array}{l}\text { Shoulder and elbow } \\
\text { arthroplasty } \\
\text { Trigger finger } \\
\text { Chronic rotator cuff repair } \\
\text { Superior labral repair } \\
\text { Tendinitis surgery }\end{array}$ \\
\hline Knee and sport & $\begin{array}{l}\text { External fixation of knee } \\
\text { dislocations }\end{array}$ & & $\begin{array}{l}\text { Repairable osteochondral } \\
\text { fractures } \\
\text { Ligament avulsion repairs } \\
\text { Acute knee loose body } \\
\text { removal } \\
\text { Locked knee from meniscal } \\
\text { tear }\end{array}$ & $\begin{array}{l}\text { ACL reconstruction } \\
\text { Multi-ligament knee } \\
\text { reconstruction }\end{array}$ & Knee cartilage repair \\
\hline
\end{tabular}


negative rate that approaches $29 \%$ in one systematic review. ${ }^{16}$ Furthermore, the test detects viral-RNA genetic sequence which consequently does not inform us as to whether the virus is alive and infectious or not. ${ }^{11,16}$ Computerised tomography (CT) scans and other blood diagnostics have been investigated to improve the sensitivity of testing but at this stage all prove to have a low specificity to diagnose COVID illness. ${ }^{14} \mathrm{~A}$ blanket policy of treating all individuals as COVID suspects is the logical progression of this argument, but again this would lead to rapid depletion of scarce PPE.

On the matter of patient risk stratification in consideration for surgery, one also has to consider the scenario that despite being asymptomatic and PCR negative, that this result is falsely negative. The greater the prevalence rate, the more likely we are to encounter this scenario, hence the importance of establishing the local infection rate. Two studies stratified community infection rates as a means to guide index of suspicion on patient positivity., ${ }^{5,13}$ They considered infection rates as low, medium or high, corresponding to infections of $<50,50-100$ or $>100$ COVID-19 cases per 100000 inhabitants. For example then, if the prevalence is high, an institution should be more aggressive in testing asymptomatic patients and in adopting the practice of treating all individuals as suspects.

If a patient should test positive and require surgery, one must also consider the physiological insult of the surgery to the body and the patient's underlying comorbidities. These have the potential to affect the severity of COVID illness. Risk factors shown to predispose patients to more severe COVID illness, and subsequent increased morbidity and mortality, include: age more than 60 years, smokers, body mass index (BMI) more than $30 \mathrm{~kg} / \mathrm{m}^{2}$, hypertension, cardiovascular disease, diabetes, respiratory dysfunction, cancer, liver and renal dysfunction. ${ }^{17}$ For this purpose it is suggested that the least invasive form of surgery be performed, and other practical applications like the use of absorbable sutures and clear wound dressings be considered to minimise follow-ups. ${ }^{18}$ Ultimately the orthopaedic surgeon will have to be flexible and considerate in their approach to the management of each patient.

\section{Summary points: Peri-operative decision-making}

- Consider the community infection rate. ${ }^{5,13}$

- Grade the urgency of the orthopaedic procedure.5,6,18

- Consider if the procedure can be performed as an outpatient. ${ }^{6}$

- Ideally screen all patients prior to surgery and if admitted, daily screening should be performed. 5,18

- Test all symptomatic patients. Test asymptomatic patients with a high risk contact. ${ }^{9}$ Maintain a high index of suspicion despite a negative result. ${ }^{11}$ Consider testing asymptomatic patients in high prevalence areas. ${ }^{9}$

- If the patient tests positive, whenever possible, surgery should be delayed or non-operative management considered. The multidisciplinary team should be involved early if surgery is pursued. ${ }^{19}$

- In emergent cases where surgery must ensue, comorbidities and physiological stress of surgery should be considered in the riskbenefit equation. ${ }^{18}$

- The least invasive surgical option should be performed. ${ }^{19}$

- Absorbable sutures and transparent wound dressings can help minimise follow-ups. ${ }^{18}$

\section{Personal protective equipment (PPE)}

SARS-CoV-2 is believed to be of zoonotic origin. ${ }^{11}$ Viral transmission has been confirmed from direct contact but the predominant mode of transmission is respiratory droplets. ${ }^{11}$ Airborne transmission can occur through the generation of aerosolised virus. Aerosols have been shown to contain SARS-CoV-2 with the potential for transmission but this is yet to be confirmed. The mode of transmission is what determines which PPE to utilise. $5,10,20-22$ Literature draws an important distinction between aerosols from cells of respiratory and intestinal origin as opposed to all other bodily fluids and tissue. ${ }^{21,22}$ The former have been shown to contain infectious virus where the latter have not. There is evidence in orthopaedic surgery, particularly when using a high-speed burr, power drills, oscillating saws, reamers, electrocautery and pulsed lavage, that blood and tissue aerosolised particles are found in an area up to $6 \times 8 \mathrm{~m}$ around the operative field. Essentially then transmission in this fashion is theoretically possible, but not proven. ${ }^{21}$

Surgical masks by design are to protect the patient from infection derived from the surgeon. In addition they have been proven to adequately protect the surgeon from infectious disease during procedures when aerosols are not generated. ${ }^{22}$ The reverse is also true: patients wearing masks afford the healthcare worker (HCW) a certain amount of protection. This protective effect occurs assuming compliance with wearing masks and attention to safe doffing. ${ }^{2}$ Respirators (such as N95 masks) are designed to protect the user and are 11.5-15.9 times more protective, with the emphasis on improved fit, seal and filtration ability. ${ }^{23}$ The European filtering face pieces (FFP) are graded 1 to 3 according to the filtration percentage of $300 \mathrm{~nm}$ particles. An FFP1 will filter $80 \%$, FFP2 filters $94 \%$ and equates to the United States (US) Centers for Disease Control and Prevention (CDC) N95 mask. The number following the ' $N$ ' in the CDC grading corresponds to the percentage of $300 \mathrm{~nm}$ particles filtered. An N95 filters 95\%, an N99 filters $99 \%$ and an N100 filters $99.97 \%$. Although the virus is on average $100 \mathrm{~nm}$ in diameter, it does not move linearly but rather it exhibits Brownian motion and as such is trapped in a filter designed for larger particles. ${ }^{23}$ Many of the recommendations support the use of powered air-purifying respirators, especially for longer duration use. These consist of a hood and have a motorised fan that directs air through a filter. They are not freely available in South Africa. ${ }^{21}$

Extended use refers to the continued use of the same respirator while treating different patients for a prolonged period of time. The current consensus on duration of use is $8-12$ hours, ${ }^{10,20}$ provided that no soiling occurs. ${ }^{10}$ It is for this purpose that some recommendations include the addition of a surgical mask over the respirator when significant contamination is expected. Reuse is defined as repeatedly donning and doffing the same FFP and does fall within the recommendations if strict donning and

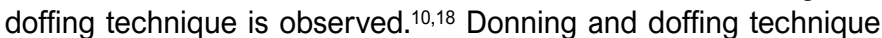
is highlighted as it is poorly performed in general. ${ }^{10} \mathrm{~A}$ study from Chicago showed incorrect doffing practice in $90 \%$ of HCWs. A different study showed a $46 \%$ self-contamination rate at the wrist and neck during doffing. ${ }^{9,11}$ Another recommendation to preserve PPE is to issue staff with five respirators. HCWs should utilise the FFP as before, but after doffing should place the FFP in a paper bag. It should remain in the bag for a minimum of 72 hours, by which time the remaining viruses are not viable, and the respirator is again regarded as safe to use..$^{18}$

Counterintuitively, surgical hoods do not provide the protection of a respirator. They are designed to protect the wearer from particles in motion but not for particle filtration. So a surgical hood alone is not protective, but can be used in conjunction with a respirator provided it is adequately cleaned between cases. ${ }^{5,20}$ Surgical gowns are rated by the Association of Advancement of Medical Instrumentation (AAMI) from 1 to 4 according to the protection they afford to the critical area, defined as the regions from cuff to elbow and chest to knees. Class 4 offers the greatest protection. ${ }^{9,21}$ Eye protection is commonplace in orthopaedic theatres but recommendations suggest that eye covering should 
extend to the areas above, below and to the sides of the eye to protect the vulnerable conjunctiva. ${ }^{21}$ Goggles with side shielding afford this protection. Double gloving is well established as the standard for orthopaedic surgery. ${ }^{21}$

\section{Summary points: Personal protective equipment (Figure 2)}

- A surgical mask, eye protection (goggles or shield), double gloving and AAMI grade 3 or 4 gowns are needed for orthopaedic surgery that entails production of aerosols.

- Additional requirements for a COVID suspect, confirmed cases or high community prevalence rate, is the use of an N95 mask or equivalent (FFP2/3). A surgical mask can be worn over the respirator if contamination is anticipated. $5,18,20,21$

- If a surgical hood is utilised it needs to be in conjunction with a respirator. ${ }^{5,20,22}$

- Extended use and re-use are recommended as preservation strategies for PPE ensuring correct donning and doffing technique and use not exceeding 12 hours. ${ }^{10,20}$

\section{Operating room considerations}

With the South African lockdown tapering and the alcohol ban lifted (at the time of writing), emergent and urgent trauma cases will increase with a concurrent rise in COVID-19 infections. ${ }^{24}$ This will result in a greater likelihood of encountering COVID-positive patients, both symptomatic and asymptomatic. The following summary points pertain to theatre complexes where at least one operating room (OR) is dedicated to the management of COVIDpositive patients, ${ }^{18}$ mindful that each patient and HCW entering the complex is a potential COVID suspect. ${ }^{9,20}$

\section{General recommendations while in the theatre complex:}

- All HCWs and patients are to practise hand hygiene and wear surgical masks. $6,8,9,18,20$

- All staff should practise social distancing. 6,8

- Regular decontamination of personal items such as stethoscopes and cellphones is to be done. ${ }^{9}$

- Theatre should run with the minimum staff required. $6,10,18$

- A negative pressure OR or an OR where there is a minimum of between 5-20 air changes per hour should be used., ${ }^{9,18-20}$ If the theatre runs on a positive pressure system then a free-standing filter should be acquired. ${ }^{10}$

- Minimise traffic through the theatre complex and each operating room. ${ }^{5,9,18}$

- All theatre surfaces should be disinfected between cases. ${ }^{18}$

\section{Recommendations for COVID theatre:}

- A path from the ward to the OR for COVID-positive patients should be identified. This path should be separate from normal traffic and disinfected after each transport of a patient. ${ }^{10}$

- The OR should have zones denoting potential risk. One recommendation refers to 'hot' and 'cold' zones where the highrisk area and OR itself is 'hot'. The 'cold' zone refers to the buffer

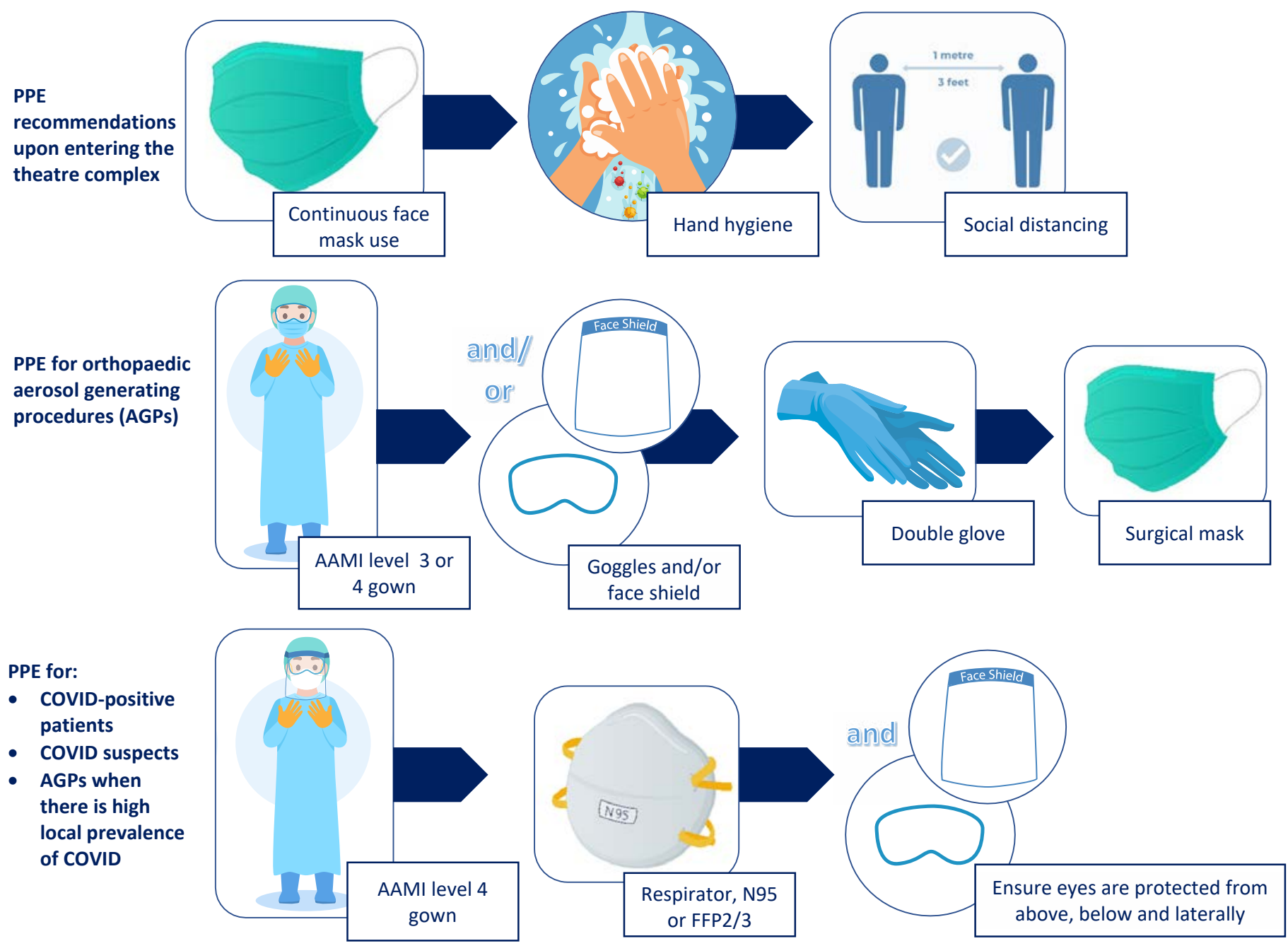

Figure 2. PPE recommendation infographic 
region between the normal areas and the hot zone., 90 There should also be isolated areas for the purpose of donning and doffing. ${ }^{9,18}$

- Only one access point should be allowed to the OR while a procedure is taking place. ${ }^{10}$

- Theatre should contain the minimum equipment required to proceed. ${ }^{18}$

- Preference is shown for regional anaesthesia to prevent respiratory aerosol generation from intubation. 5,10,18

- If intubation is required it is recommended that it be performed by the most senior anaesthetist present. ${ }^{10}$ Only the two people involved with the intubation should be in the OR during this time to decrease the number of staff exposed. ${ }^{18}$ Alternatively the intubation can occur outside the OR in a designated area like an ICU. 5,18

- Post-operatively the patient should be recovered in the OR. This will mitigate the risk of exposure to other patients in the general recovery room. ${ }^{10,18}$

- One should allow adequate time to elapse post-intubation before entering theatre and similarly, post-operatively a certain amount of time should elapse prior to re-entry to start decontamination. This timing is relative to the amount of air changes per hour of the filtration system, where each change removes $63 \%$ of the virus. ${ }^{25}$ Most guidelines suggest that in 20 minutes the viral load is negligible; however, it is recommended to determine the individual specifications of each theatre complex. ${ }^{9,18}$

\section{Patient outcome studies}

While travel restrictions have decreased the high-energy motor vehicle accident (MVA) rate, patients still require orthopaedic trauma care due to, for example, low-energy falls. These patients will now encounter a resource-depleted healthcare system adapted for COVID-19. They will be susceptible to severe COVID illness as they are usually elderly, frail, have multiple comorbidities and are slow to ambulate, predisposing them to the usual respiratory illness and COVID illness. ${ }^{14}$ Prior to the COVID era, a mortality rate of $20-40 \%$ was reported for these patients, $7-8 \%$ of these occurring within the first 30 days. These vulnerable patients now risk contracting SARSCoV-2 in healthcare facilities where COVID cases are centralised. ${ }^{5}$

Thus far, three observational studies have been performed on patients with fractures and concomitant COVID illness. The initial study originated from Wuhan at the epicentre of the pandemic. ${ }^{14}$ A retrospective cohort of six confirmed COVID-positive (PCR test of oropharyngeal swabs) and four highly suspicious patients (CT features suggestive of a viral pneumonia) who all had concomitant fractures, were included. A mortality rate of $40 \%$ was observed (four out of ten), four of the deaths were recorded in patients with comorbidities and the fourth had a concomitant brain injury. Three out of ten patients had a community-acquired infection and the rest nosocomial. The most common symptoms were fever, cough and fatigue, each found in $70 \%$ of cases. Ninety per cent of patients had abnormal d-dimer results. Seven out of eight patients had raised procalcitonin, and all patients in whom c-reactive protein (CRP) was tested had an elevated result. Nine required supplemental oxygen and three non-invasive ventilation (ventilators were unavailable to these patients). All four patients died within two weeks of admission and three of those were not operated. The small sample size and lack of control group limit what can be concluded from this study.

This study highlights:

- The need for strict infection control measures to limit nosocomial transmission of the disease.

- Common symptoms of COVID disease in fracture patients including fever, cough and fatigue.
- Multiple sensitive but non-specific laboratory findings.

- The need for supplemental oxygen in most patients.

- A mortality rate of $40 \%$ in COVID-positive patients with concomitant fracture.

The next study was conducted in Italy using the STROBE guidelines. It had a study population of 16 COVID-positive patients (diagnosed with CT scan and oropharyngeal PCR) with a proximal femur fracture. Three patients died pre-operatively and four died within seven days post-operatively; all deaths were attributed to respiratory failure. Either a cephalomedullary nail or hemiarthroplasty was performed within three days of admission, and patients were mobilised the day after surgery. Again, inferring conclusions from this study is difficult due to lack of a comparative sample.

This study highlights:

- A $44 \%$ early mortality rate in COVID-positive patients with proximal femur fractures.

- Similar mortality rates, irrespective of receiving surgery or not.

A Spanish cohort study had the largest study population and aimed to assess the mortality rate of elderly patients with proximal femur fractures within a pandemic environment. ${ }^{13} \mathrm{~A}$ total of 136 patients were identified with a mean age of 85 years. Of them, 23 were SARS-CoV-2 positive on oropharyngeal PCR swabs, 39 were negative and 74 were unknown. Seventy patients came from high risk areas (>100 positive cases per 100000$)$ reflecting the high infection rate in Spain during this time. Within a mean of 2.4 days, 124 patients were operated. The remainder were not operated as they were deemed too unstable or had demised. A total of 13 patients died. Seven of these were COVID-positive cases, representing a $30.4 \%$ mortality rate in COVID-positive patients and $10.3 \%$ for COVID-negative patients. The study was designed to assess the mortality rate in the midst of a pandemic, so mention was made that the 14-day mortality rate of this cohort $(9.6 \%)$ was higher than the 30-day mortality rate recorded in the Spanish Hip registry of patients with comparative age and American Society of Anesthesiologists (ASA) classification.

There are several limitations of this study. There were 74 COVIDunknown patients, which introduces a potential bias. Potentially the more ill patients were selected for testing and would consequently have a higher mortality rate. Secondly, the established high false negative rate of PCR testing was mitigated in the previous two studies with the use of CT scanning to aid in diagnosis. Interestingly the study did not discuss that the mortality rate of COVID-negative patients in this cohort was higher than that recorded in the Spanish national registry for similar patients. This raises the concern that the pandemic is possibly resulting in an increased morbidity and mortality rate to the uninfected orthopaedic patient because of resource constraints or other limitations posed by the crisis.

This study highlights:

- $30.4 \%$ mortality rate in COVID-positive patients with hip fractures.

- $10.3 \%$ mortality in COVID-negative patients.

\section{Orthopaedic surgeons}

HCWs are at an increased risk for contracting COVID-19 disease as hospitals are high zones of transmission. ${ }^{19}$ There is an increased risk of developing more severe illness, shown to be the case with increased viral exposure. ${ }^{21}$ The crisis renders HCWs emotionally and physically exhausted, and they are further stretched when colleagues fall ill, as provision of healthcare must be maintained with fewer team members. Orthopaedic surgeons are providing 
less orthopaedic-related care and performing more duties outside their scope of practice. This was highlighted in an online survey completed by 136 European orthopaedic surgeons, concluding an overall reduction in orthopaedic activity of $73 \%$. In the same survey $49 \%$ of respondents reported that either they themselves or a colleague had been shifted into the management of COVID patients. ${ }^{26}$ Finally, there is the prevailing concern of transmitting the virus to our families. Three studies elaborated on the effects the pandemic has had on orthopaedic team members and the implications thereof

A cross-sectional study, by way of online survey, was distributed to SARS-CoV-2 infected orthopaedic surgeons in Wuhan. The same survey was distributed to an age-matched uninfected group. The questionnaire engaged surgeons on their behaviours and practices during the preceding months. ${ }^{2}$ Redeployed surgeons treating COVID patients were excluded. Twenty-four COVIDpositive surgeons with a mean age 36.1 years (range 25-48) were identified; only one reported comorbid diabetes. Of them, $79 \%$ suspected they contracted the disease in a general ward. The most common symptoms were fever, cough and fatigue; 15 required hospitalisation, but all made a full recovery. In $25 \%$ of cases, transmission occurred to patients, colleagues, family and friends. A troubling finding was that $80 \%$ of these transmissions were to family members. Regression analysis showed no demographic differences to the age-matched control group. Not wearing an N95 respirator increased risk of contracting the virus (odds ratio of 5 and $p=0.004$ ). Compliance with the correct technique of mask wear and a knowledge of infection control and prevention guidelines were found to be protective (odds ratio $0.15, p=0.004$ and odds ratio $0.12, p=0.007$ respectively).

This study highlights:

- Most infections occurred in the general (non-COVID) wards - deduced by the authors to be as a result of a false sense of security in wards not allocated for COVID patients.

- The symptomatology was mild with $100 \%$ recovery rate, albeit only one positive surgeon had a comorbidity.

- Compliant wearing of an N95 mask and a knowledge of infection control guidelines contribute to reducing the risk of contracting the virus.

- There was a high number of virus transmissions to family members.

A second web-based survey charted the qualitative impact of the pandemic on arthroplasty sub-specialty residents, fellows and junior consultants. ${ }^{27}$ This survey was distributed to arthroplasty surgeons in particular, so while it offers some insight, no deductions can be drawn for other orthopaedic sub-disciplines.

This study highlights:

- There was a $25 \%$ redeployment rate.

- $56 \%$ of respondents reported a change to their monetary compensation.

- With regard to trainees, $84 \%$ felt they had received adequate training to continue with exams, while $16 \%$ felt their exams may be delayed leading to a prolonged training time.

A third survey aimed to assess orthopaedic surgeon stress levels in India during their national lockdown. ${ }^{28}$ Responses were received from 611 surgeons, the majority of whom were between 30 and 40 years of age. Most worked in the private sector only and performed no state work. Twenty-three per cent reported being 'definitely stressed out' and $58 \%$ reported their work/life balance had been reversed. Twenty-eight per cent of respondents were not stressed at all. Interestingly $55 \%$ thought things would return to normal a couple weeks after the lockdown had ended in India. Seventy per cent considered doing research during the lockdown. A younger age and an altered work/life balance were significantly associated with those feeling 'definitely stressed out'.

This study highlights:

- The emotional toll the pandemic has on orthopaedic surgeons is evident.

\section{Discussion}

This scoping review highlighted the need for further study with regard to COVID-19 and orthopaedics. While there are numerous publications, most were institutional experiences or situational reports commenting on surgeons' attempts to streamline their own practice during this time. There remains a paucity of scientific evidence-based research and several gaps have been identified.

With regard to peri-operative considerations, patient stratification remains non-standardised and decisions to operate patients are largely at the discretion of the surgeon or institution. Patient management would benefit from the development of a test for SARS-CoV-2 that is both rapid, sensitive and specific. In the OR it is unknown whether aerosolised tissues containing virus other than respiratory and intestinal are able to cause disease, knowledge of which could better guide PPE use.

The patient outcome studies at present are limited. Case control studies are needed with matched comorbidities or regression analysis of comorbidities comparing COVID and non-COVID patients with fractures who demise. This would help determine if mortality and morbidity is in fact increased in COVID-positive patients. The current studies focus on morbidity and mortality in a vulnerable population; it is possible that the pandemic may also be affecting healthy patients with emergent and urgent orthopaedic surgery requirements, for which there are no studies at present.

Orthopaedic surgeons have contracted the virus and fortunately recovered. However, they have experienced other negative consequences as a result of the pandemic. Regarding the work environment, many have been redeployed, many are receiving reduced compensation and many trainees face doubtful futures. The reasons for distress arising out of the crisis have been identified and can serve to help us recognise and address them as the COVID surge ensues.

The main limitation of this study is that scant evidence-based methodological studies are available at present. The pandemic is evolving rapidly and so too is the research thereon. It is highly probable that more articles meeting the inclusion criteria will be available at time of publication of this study. At the time of the review, there were also no South African studies on orthopaedic patients with COVID disease; these will be necessary in order to guide practice in our uniquely challenged health system.

\section{Conclusion}

Orthopaedics is significantly affected by the COVID pandemic. Orthopaedic surgeons, despite the emotional and physical toll on themselves, need to remain abreast of the strategies to safely continue surgery and maximise favourable patient outcomes. More scientific study is required to make informed decisions in this regard.

\section{Ethics statement}

The authors declare that this submission is in accordance with the principles laid down by the Responsible Research Publication Position Statements as developed at the 2nd World Conference on Research Integrity in Singapore, 2010. Ethical clearance was not required as no human participants were involved in the generation of this article. This article is a systematic literature review and therefore does not involve a study with human or animal participants performed by any of the authors. 


\section{Declaration}

The authors declare authorship of this article and that they have followed sound scientific research practice. This research is original and does not transgress plagiarism policies.

\section{Author contributions}

MO contributed to conceptualisation, design, literature review, study screening and selection, data analysis and manuscript preparation.

LN contributed to design, literature review, study screening and selection, data analysis and manuscript review.

LCM contributed to conceptualisation, design and manuscript review.

\section{ORCID}

O'Connor M (iD) https://orcid.org/0000-0001-8864-4916

Nieuwoudt L id https://orcid.org/0000-0002-1309-2210

Marais LC (iD) https://orcid.org/0000-0002-1120-8419

\section{References}

1. Abdool Karim SS. The South African response to the pandemic. New England Journal of Medicine. 2020;382:e95. https://doi.org/ 10.1056/NEJMc2014960.

2. Guo X, Wang J, Hu D, et al. Survey of COVID-19 disease among orthopaedic surgeons in Wuhan, People's Republic of China. Bone Joint Surg Am. 2020. https://doi.org/10.2106/jbjs.20.00417.

3. PRISMA Extension for Scoping Reviews (PRISMA-ScR): Checklist and explanation. Ann Intern Med. 2018;169:467-73. https://doi.org/ 10.7326/m18-0850\%m30178033.

4. American College of Surgeons. COVID-19 guidelines for triage of orthopaedic patients. Available from: https://www.facs.org/ covid-19/clinical-guidance/elective-case/orthopaedics (2020).

5. Service BC, Collins AP, Crespo A, et al. Medically necessary orthopaedic surgery during the COVID-19 pandemic: safe surgica practices and a classification to guide treatment. $J$ Bone Joint Surg Am. 2020. https://doi.org/10.2106/jbjs.20.00599.

6. Massey PA, McClary K, Zhang AS, et al. Orthopaedic surgica selection and inpatient paradigms during the coronavirus (COVID19) pandemic. J Am Acad Orthop Surg. 2020;28:436-50. https:// doi.org/10.5435/jaaos-d-20-00360.

7. Tay K, Kamarul T, Lok W, et al. COVID-19 in Singapore and Malaysia: Rising to the challenges of orthopaedic practice in an evolving pandemic. Malays Orthop J. 2020;14(2). https://doi. org/10.5704/MOJ.2007.001.

8. Ding BTK, Decruz J, Kunnasegaran R. Time-sensitive ambulatory orthopaedic soft-tissue surgery paradigms during the COVID-19 pandemic. Int Orthop. 2020 https://doi.org/10.1007/ s00264-020-04606-w.

9. Awad ME, Rumley JCL, Vazquez JA, et al. Peri-operative considerations in urgent surgical care of suspected and confirmed COVID-19 orthopedic patients: operating rooms protocols and recommendations in the current COVID-19 pandemic. J Am Acad Orthop Surg. 2020. https://doi.org/10.5435/JAAOS-D-20-00227.

10. Kumar A, Kumar A, Das S. Perioperative COVID-19 testing of orthopedic patients: Current evidence. J Clin Orthop Trauma. 2020. https://doi.org/10.1016/j.jcot.2020.04.031.

11. Yung CS-Y, Fok $\mathrm{KCH}$, Leung $\mathrm{CN}$, et al. What every orthopaedic surgeon should know about COVID-19: A review of the current literature. Journal of Orthopaedic Surgery. 2020;28:2309499020923499. https://doi.org/10.1177/230949 9020923499

12. Lei $\mathrm{S}$, Jiang $\mathrm{F}, \mathrm{Su} \mathrm{W}$, et al. Clinical characteristics and outcomes of patients undergoing surgeries during the incubation period of COVID-19 infection. EClinicalMedicine. 2020;21:100331. https:// doi.org/10.1016/j.eclinm.2020.100331.

13. Muñoz Vives JM, Jornet-Gibert M, Cámara-Cabrera J, et al Mortality rates of patients with proximal femoral fracture in a worldwide pandemic: preliminary results of the Spanish HIP-COVID observational study. J Bone Joint Surg Am. 2020. https://doi.org/10.2106/jbjs.20.00686.

14. Mi B, Chen $\mathrm{L}$, Xiong $\mathrm{Y}$, et al. Characteristics and early prognosis of COVID-19 infection in fracture patients. J Bone Joint Surg Am . 2020. https://doi.org/10.2106/jbjs.20.00390.

15. Catellani F, Coscione A, D'Ambrosi R, et al. Treatment of proximal femoral fragility fractures in patients with COVID-19 during the
SARS-CoV-2 outbreak in Northern Italy. J Bone Joint Surg Am. 2020. https://doi.org/10.2106/jbjs.20.00617.

16. Woloshin S, Patel N, Kesselheim AS. False negative tests for SARS-CoV-2 infection - challenges and implications. $N$ Engl $J$ Med. 2020. https://doi.org/10.1056/NEJMp2015897.

17. Vannabouathong C, Devji T, Ekhtiari S, et al. Novel coronavirus COVID-19: current evidence and evolving strategies. J Bone Joint Surg Am. 2020;102:734-44. https://doi.org/10.2106/jbjs.20.00396.

18. Prada $\mathrm{C}$, Chang $\mathrm{Y}$, Poolman $\mathrm{R}$, et al. Best practices for surgeons. COVID-19 evidence-based scoping review. Orthoevidence. 2020. https://doi.org/10.13140/RG.2.2.20752.76809/1

19. Tang PF, Hou ZY, Wu XB, et al. Expert consensus on management principles of orthopedic emergency in the epidemic of corona virus disease 2019. Chin Med J. 2020. https://doi.org/10.1097/ CM9.0000000000000810.

20. Fillingham YA, Grosso MJ, Yates AJ, et al. Personal protective equipment: current best practices for orthopedic teams. J Arthroplasty. 2020. https://doi.org/10.1016/j.arth.2020.04.046.

21. Hirschmann MT, Hart A, Henckel J, et al. COVID-19 coronavirus: recommended personal protective equipment for the orthopaedic and trauma surgeon. Knee Surg Sports Traumatol Arthrosc. 2020. https://doi.org/10.1007/s00167-020-06022-4.

22. Basso $\mathrm{T}$, Dale $\mathrm{H}$, Langvatn $\mathrm{H}$, et al. Virus transmission during orthopedic surgery on patients with COVID-19 - a brief narrative review. Acta Orthop. 2020:1-4. https://doi.org/10.1080/17453674. 2020.1764234

23. Viswanath A, Monga P. Working through the COVID-19 outbreak: Rapid review and recommendations for MSK and allied heath personnel. J Clin Orthop Trauma. 2020. https://doi.org/10.1016/j. jcot.2020.03.014.

24. The Washington Post. South Africa's alcohol ban during lockdown reveals its deadly drinking habits. Available from: https://www. washingtonpost.com/world/africa/south-africa-coronaviruslockdown-alcohol-ban/2020/05/09/a2b964a2-8eef-11ea-9322a29e75effc93 story.html (2020).

25. Cook TM. Personal protective equipment during the coronavirus disease (COVID) 2019 pandemic - a narrative review. Anaesthesia 2020;75:920-27. https://doi.org/10.1111/anae.15071.

26. Ranuccio F, Tarducci L, Familiari F, et al. Disruptive effect of COVID-19 on orthopaedic daily practice: a cross-sectional survey. J Bone Joint Surg Am. 2020 Jul 15;102(14):e77.

27. Culp BM, NB Frisch. COVID-19 impact on young arthroplasty surgeons. J Arthroplasty 2020. https://doi.org/10.1016/j. arth.2020.04.058.

28. Sahu D, Agrawal T, Rathod V, et al. Impact of COVID-19 lockdown on orthopaedic surgeons in India: A survey. J Clin Orthop Trauma. 2020. https://doi.org/10.1016/j.jcot.2020.05.007. 